\title{
BOTTOM SQUATTED SETTLEMENTS VS. TOP GATED COMMUNITIES: A NEW DIRECTION OF SOCIAL SEGREGATION IN SANA'A CITY
}

\author{
Al-Abed, Abdullah \\ Department of Architecture, Faculty of Engineering,Sana'a \\ University, YEMEN. \\ E-mail: $\underline{\text { dralabed92@yahoo.com }}$
}

(Received April 2, 2011 Accepted July 31, 2011)

\begin{abstract}
Since 1960's the phenomenon of urban social segregation has been developed in Sana'a city in three consecutive zones. These are the indigenous, transitional and spontaneous zones. The architecture of the indigenous zone was not used as a means to express wealth and status of the inhabitants. The trend in the transitional zone was 'softly segregated'. To examine the new direction of social segregation between bottom squatted settlements and top gated communities in the fringe "spontaneous zones" of Sana'a city, this study adopted an investigatory approach and utilised multiple qualitative methods.

Evidence in this paper reveals that social segregation between the well-off in gated communities and concentrated poverty in squatted settlements is blurred in the peripheral zone of the case study city.
\end{abstract}

KEYWORDS: gated communities, squatted settlements, social segregation, Sana'a, Yemen.

\section{INTRODUCTION}

Sana'a experienced an unprecedented population increase since the 1960s, spurred by a massive migration from the rural areas, and grew to be the largest metropolis of Yemen with a population estimated to be over 2 million.

Until very recently, similar to other cities in Yemen, housing supply in Sana'a has been changed from indigenous to spontaneous type of housing.( Al-Abed, 2003 ).

Outside the gated old city, apartment neighbourhoods constituted the legally constructed areas located in the central parts of the city and were built in piecemeal fashion by small firm contractors. Squatted settlements, on the other hand, were typically located on the outskirts of the city and were built illegally by the urban poor and migrants on often-occupied public land without any infrastructure. In addition to differences in legal tenure and mode of provision, apartments and squatted settlements also reflected divisions of class and culture, and symbolic hierarchies that go with them. Living in an apartment in the central parts of the city was symbolic of a middleclass status, a modern and urban lifestyle, whereas living in a squatted settlements was deemed as the symbol of a peasant way of life, backwardness and a lower-class disposition.

Despite this dualist structure of the city's residential landscape, Sana'a was a 'softly segregated' city until the 1980s. Both neighbourhoods of apartments and squatters displayed considerable heterogeneity in terms of their residents' social class 
and status. The former hosted different segments of middle classes as well as working classes.

Since the 1990s, both the housing market and the residential landscape of the city have undergone a dramatic transformation. While apartment housing has become the dominant form, outstripping the spread of squatted settlements, the secular trend among middle- and upper income groups is towards detached villa types and masterplanned projects of various scales rather than single apartment housing developments.

This transition from old to new patterns has been reshuffling diverse social groups and paving the way to a more complex and fragmented city. One can now find squatted settlements on the outskirts steadily being colonized by disadvantaged and low-income groups and gated projects for well-off and upper middle-income groups. These gated communities are mushrooming in unexpected places and walling themselves off from their surrounding neighbours. Although they have a relatively short history, their number has increased geometrically.

Gated communities display considerable variation in terms of location, size, design and the amenities they offer. Notwithstanding these differences, however, they are all compound units offering a favorable infrastructure and a variety of private services for socially and economically homogeneous elites, mixing the characteristics of the prestige, security and lifestyle communities found world wide.

This paper therefore, emphasizes that the contemporary development of squatted settlements and gated communities in Sana'a, since the 1990s, conforms to global trends in the privatization of space and social segregation. The development of gated communities thus represents a new phase of residential segregation. It is based primarily on income, privacy, prestige, and driven by intensifying exclusionary market pressures. It has been an outcome of top-down public policies typically attributed to urban planning malfunction approaches.

\subsection{Methods and Research Organization}

Given the limited research and literature on squatted and gated developments in Sana'a, this paper adopted an investigatory approach and utilised multiple qualitative methods ranging from a review of documentary material, to field work survey, to semistructured in-depth interviews, and participant observation.

The research proceeded in three successive stages. First, field work survey was conducted in three consecutive development zones of the city. That is to identify the evolution of housing development and socio-spatial segregation in the city since 1960s until now. Second, different squatted and gated communities were identified depending on their characteristics and accessibility. Through regular visits to these communities, it has been observed their characteristics and has been conducted interviews with the sales, marketing, public relations and management personnel and presidents of the community or property owners. It also has been analysed documentary sources made available, such as publicity brochures, community bulletins, collections of advertisements published in various papers and magazines.

In the third stage, fieldwork has been conducted. The purpose of this fieldwork was to develop an in-depth understanding of the production of squatted and gated communities, the nature of the social and built environment that the users seek to 
establish and the characteristics of community and lifestyle that have been attracting Sana'a's lower and upper classes.

Participant observation has been also conducted to observe daily life and achieve an adequate overview of the characteristics of the enclaves. Participant observation included accompanying residents to some community and family events and public spaces such as cafe's, mosques and cultural activities.

In all stages, interviews with questions loosely designed according to the interviewees' identity were used. Thus, interviews with residents enquired about topics such as family and personal histories, the reasons they have chosen to live in their communities, their daily life and social interactions in the community, their perception of the city and their images of themselves and of other social groups. Interviews with other individuals focused on the history of the squatted and gated development, the particular lifestyle and identity they have tried to promote through the social and built environment.

In addition to the introduction and conclusion this paper has been organized in four sections as follows:

- Gated Communities and Social Segregation (Review of Literature)

- Evolution of Sana'a Socio-Spatial Segregation

○ (Zone A) The old walled gated city

- (Zone B): Transitional zone (beyond the old wall until the 60th Street).

○ (Zone C): Squatted and Gated communities zone (beyond 60th Street)

- Bottom squatted settlements.

- Top gated communities.

\section{GATED COMMUNITIES AND SOCIAL SEGREGATION (REVIEW OF LITERATURE)}

Gated communities have become an important theme in contemporary debates on the production of urban spaces (Blakely and Snyder, 1997, Webster et al., 2002, Marcuse,1997, McKenzie, 2005, Atkinson and Blandy, 2005, Glasze et al., 2006,; Genis, 2007). Most commonly reflects aspirations of the upper and middle classes for enhanced segregation.

The global spread of this phenomenon has been studied in the past decade from different perspectives. Gated communities thus have some variations among the US, Europe, and Latin America. In US and Europe there are three types of gated communities, which are referred to as Lifestyle, Prestige, and Security zone. two means:

In Latin America gated communities are sealed off from their surrounding by

- Privatization of public space, it started with the closure of streets, followed by section of public space and erection of residential quarters behind high walls and fences, with sophisticated security measures. It resulted in the construction of private highways linking several exclusive quarters or cities, accessible not to the public but only to the citizens of these districts.

- By means of social-exclusion, territorial informal settlements have been segregated from the planned areas. 
The processes of social segregation and concentration of poverty has been a heavily discussed issue among scholars since the 1980s (De La Rocha et al., 2004; Fainstein, 1996; Portes \& Hoffman, 2003; Marcuse, 1996; Wacquant, 1996). All of these discussions point out the social polarization of urban population due to the social exclusion in the central areas of the metropolitan industrialized cities. Concepts like "new poverty", "hyper-segregation" and "concentrated poverty" have become to define socially and economically disadvantaged groups. However, the social upgrading in these cities leads to urban gentrification. The development of gentrification seems to correlate to globalization processes. When Sana'a compared to these cities, globalization is not a central issue. Globalization phenomenon has had an extremely uneven impact on Sana'a city. Therefore, this paper points out that social segregation and concentration of poverty are scattered in fringe of the city rather than urban inner areas.

\section{EVOLUTION OF SANA'A SOCIO-SPATIAL SEGREGATION}

In order to have general understanding of socio-spatial segregation of the urban structure as well as the gated communities in Sana'a city since 1960's, the city spatially has been divided into three zones. As shown in Fig.(1)these are as follows:

- (Zone A): The old walled gated city.

- (Zone B): Transitional zone (beyond the old wall until the $60^{\text {th }}$ Street).

- (Zone C): Squatted and Gated communities zone (beyond $60^{\text {th }}$ Street)

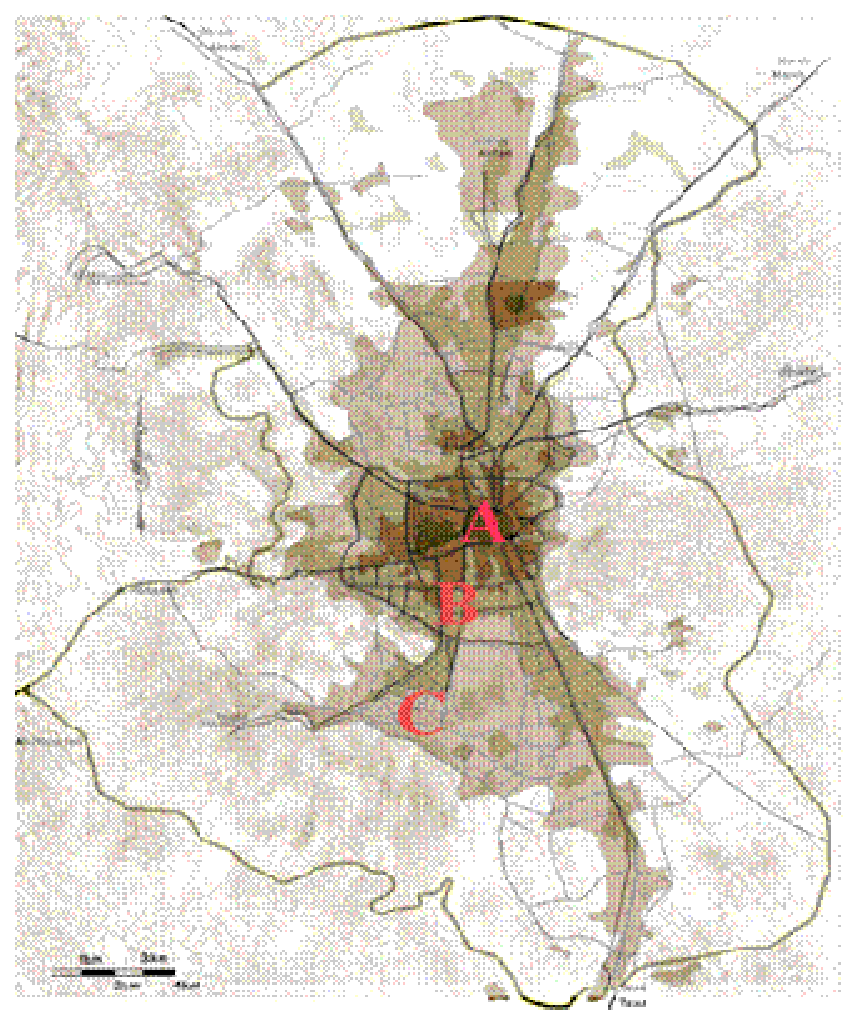

Figure 1 : Sana'a's socio-spatial segregation three zones 


\section{1. (Zone A) The Old Walled Gated City}

As demonstrated in Fig. (2) this part of the city is characterized by a dense, compact residential area, with narrow winding alleyways, a hierarchy of open streets and an urban pattern and social solidarity which is based on a shared religious identity and homogenous community.

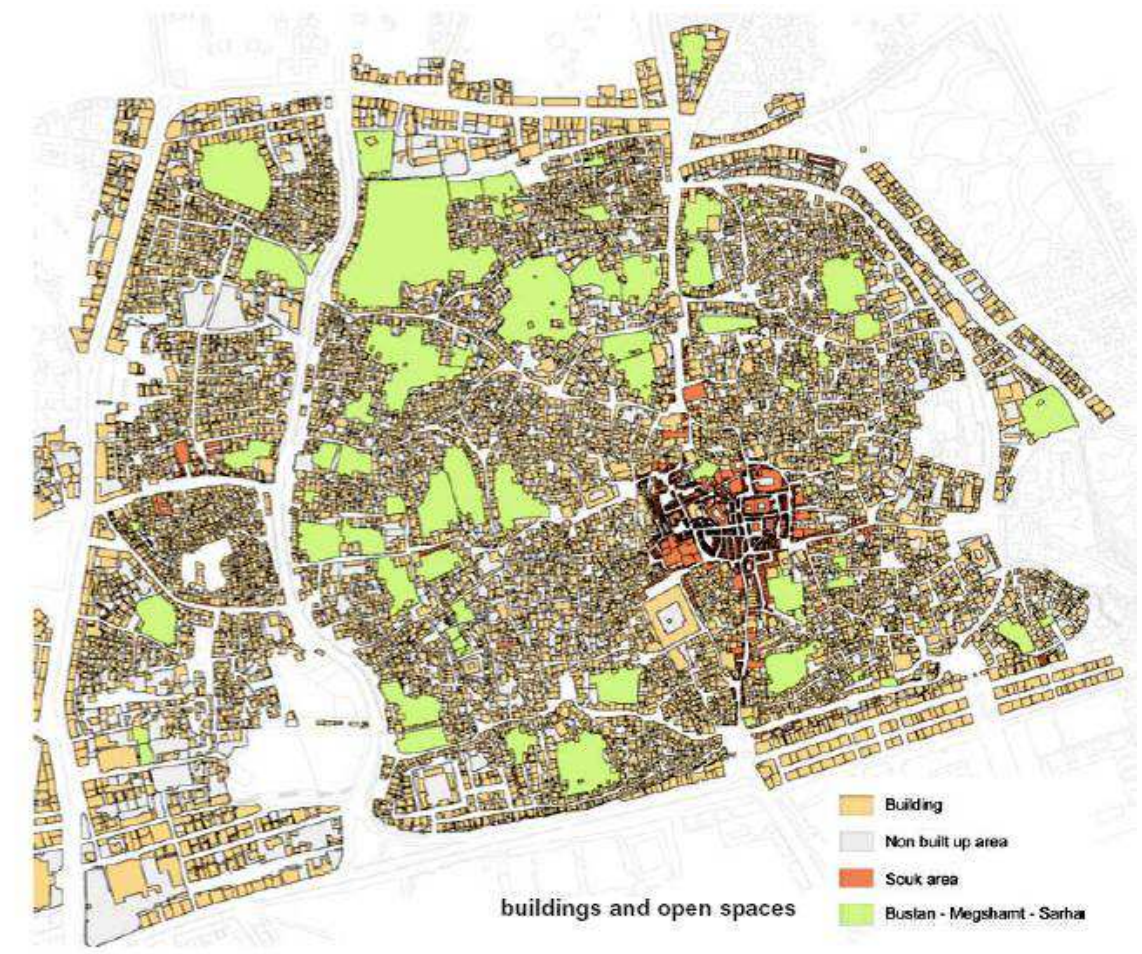

Figure 2: Old walled gated city

Source: Pini, D., et al. (2008)

The gated city was developed by the inhabitants on the basis or the concept of "urf" (action of belief in which persons persist with the concurrence of reasoning power and with their natural disposition). This means an agreement among the people who live there to leave open spaces, i.e. alleyways, streets....etc. which result in (haras) planned according to the inhabitants' socio-cultural needs (Fig. 3).

The 65 (haras') streets pattern demonstrate a gradual transition from public spaces composing wide streets and also the 'suq' through the pedestrian lanes and finally to the private dead-end streets and privacy of the inhabitants' houses.

The spatial organization of the walled gated city emphasizes human scale built for man and reflects the harmonious relationship man and his environment have with each other.

Up until 1960s the entire old part of the city was dominated by one type that was the tower indigenous sanani house Fig.(4\& 5). The indigenous house of Sana'a illustrates its domestic unique vernacular architecture. It is interesting to note that spontaneous housing does not exist in this zone Fig. (4). 


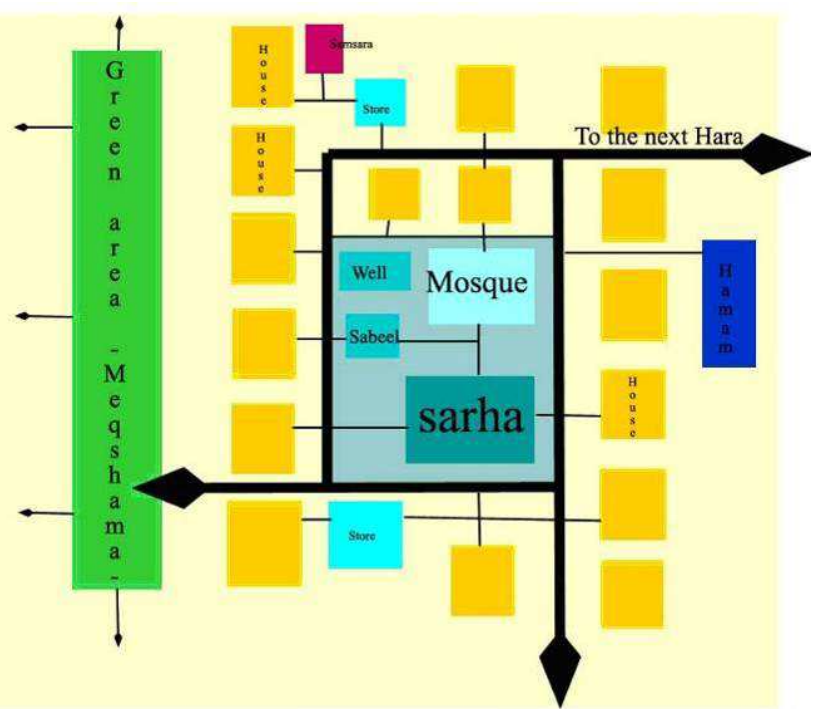

Figure 3: The concept of traditional neighborhood (hara)

Source: A.E.C.(2005)

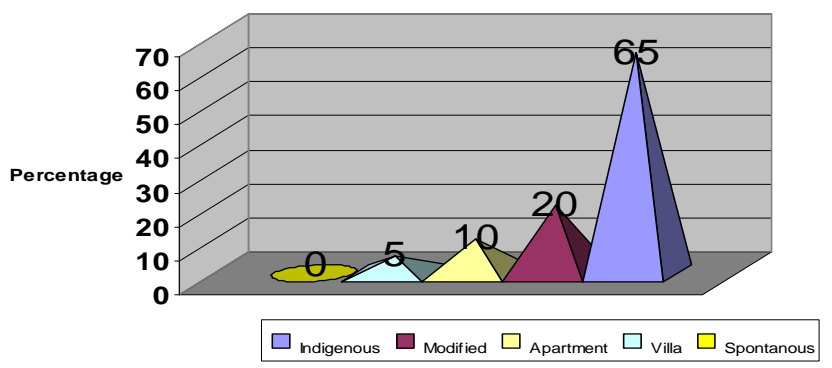

Figure 4 : Housing types in the indigenous zone

It represents one example of homogenous Islamic architecture. It is the outward multi-storey Islamic house Fig.( 5).

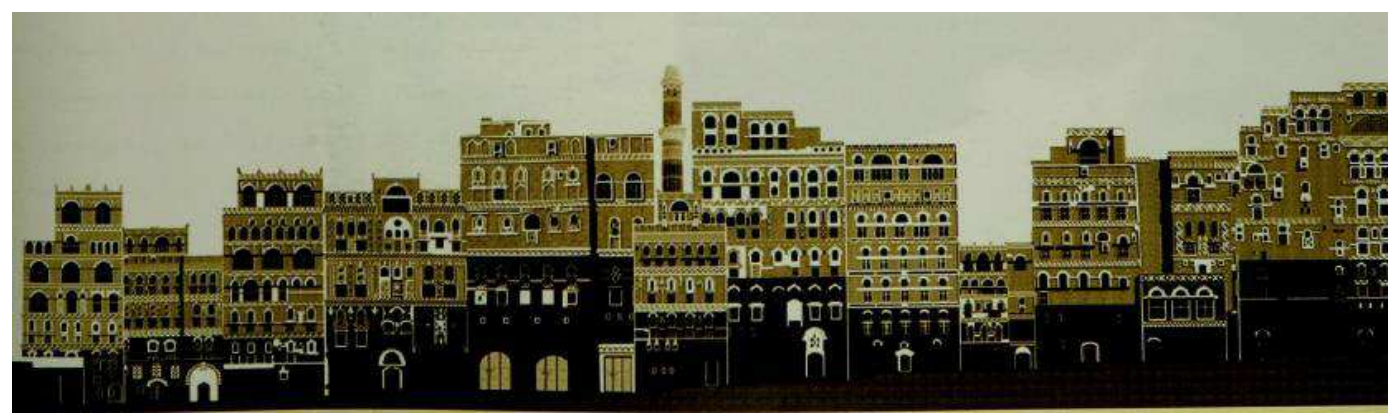

Figure 5 : Tower indigenous Sanani houses

Source: (A.E.C.2005) 
Built environment unity was one of the characteristics of the indigenous part of Sana'a. There were very few distinctions between the houses of rich people and those of the less well off. It is interesting to note here that architecture was not used as a means to express wealth and status of the inhabitants.

\section{2 (Zone B): Transitional zone (beyond the old wall until the 60th Street)}

This Zone is considered to be that part of the city outside the walls and along radial major roads. This sector was constructed mainly between 1970s and 1990s.

Consequently, the first ring road (Al-dairy) and second ring road (Assteen) played a major role in the overall image of the transitional part of the city. New structures were erected along them, and the area in between the roads was filled with various residential areas. Yet, under the pressure of urban extension, residential areas had extended beyond the boundaries proposed by Sana'a Master Plan.

The urban structure of the transitional area completely changed from an organic pattern to a pattern of geometrical shapes in a short period of time.

As mentioned above, the overall pattern of the transitional area is affected by the concept of the Master Plans that are based on western models of development.

The city is divided into 9 planning sectors, each sector is divided into 9 areas and each area is divided into 9 neighborhoods. The neighborhood ranges from 45-60 hectares with an estimated population ranges from 7,000 up to 12,000 persons. Each neighborhood is planned to have a primary school, garden and mosque and in case the population reaches 12,000 a post office, police office and a high school should be included in the neighborhood plan.

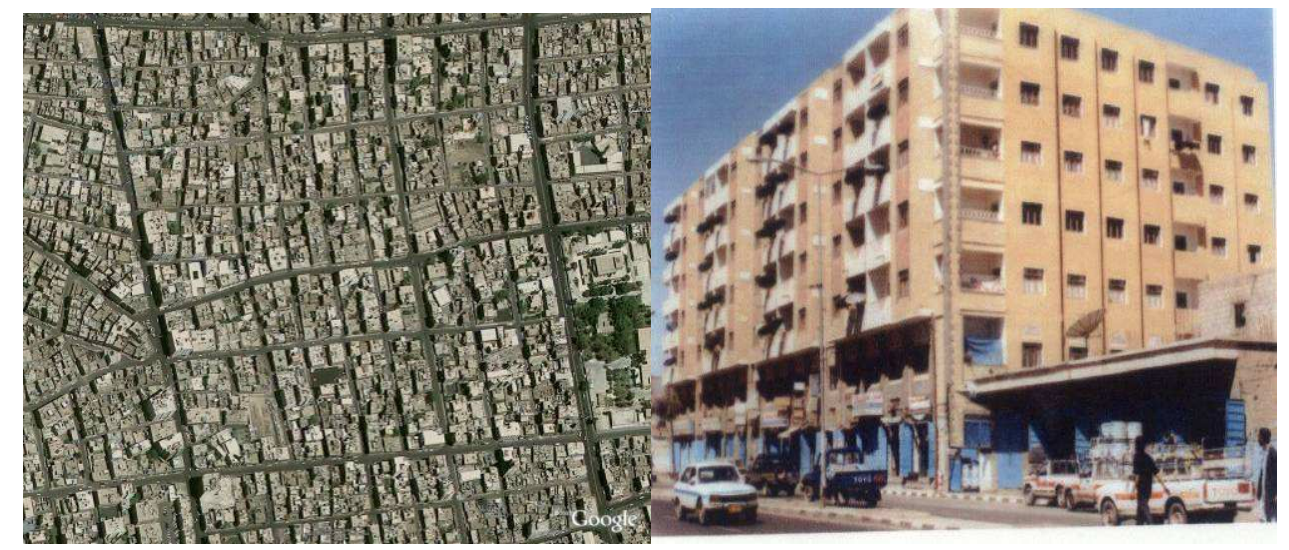

Figure 6 : Urban fabric and the apartment building type in the transitional zone

The basic urban structure of the transitional area is alike, looking at the aerial map of the city, one can see the closeness and similarity of the urban anatomies. The grid -iron street pattern, buildings standing in the middle of the plots, the square and rectangular shapes of flat-roofed buildings, etc., all combine to give the transitional area a distinctive urban form contrasts with that of the indigenous area (see Fig.6). The houses disunity has become a major feature of the transition zone. The trend in the transitional zone was the coexisting of different social groups. 


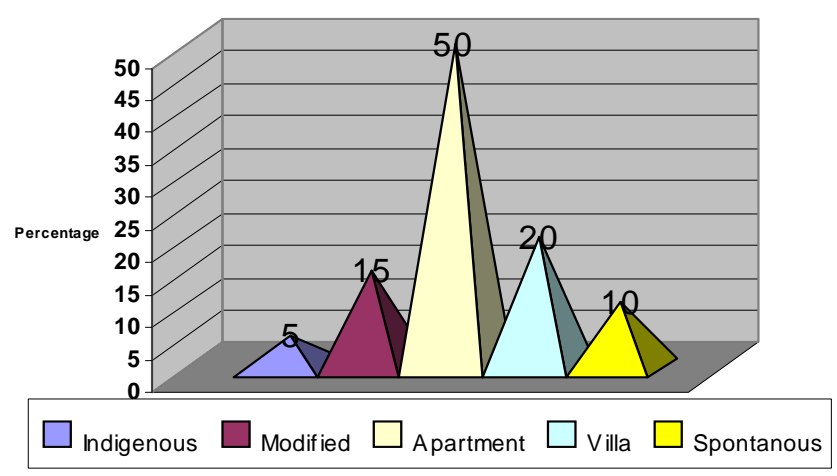

Figure 7 : Housing types in the transitional zone

Therefore, there are many different types of dwelling which can be found in the transitional area. These could be categorized as the modified indigenous traditional houses, apartment buildings, villas and spontaneous houses (Fig. 7).

\section{3. (Zone C): Squatted and Gated communities zone (beyond 60th Street)}

The area under consideration is that which has developed between 1990s and the present time beyond 60th Street.

Based on arial photographs there is a remarkable difference between the built fabric of the indigenous part and transitional area with this zone. As shown in Fig. (8), housing types in this zone are dominated by villas (40\%) and spontaneous houses $(30 \%)$. The indigenous housing type represents only $(5 \%)$.

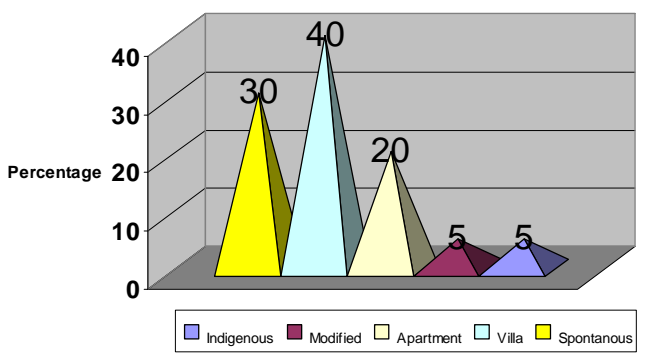

Figure 8 : Housing types in the spontaneous zone

The 39 poor squatted settlements are unplanned areas encircling planned gated communities (Fig.9). 


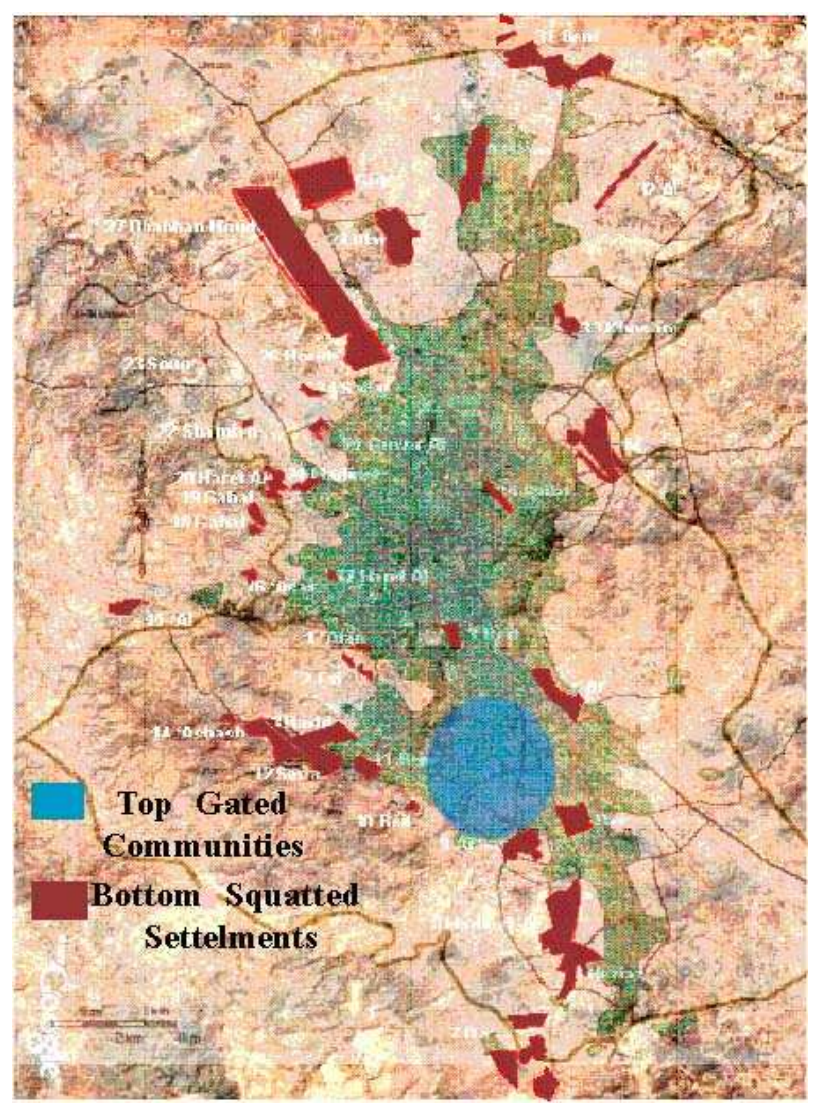

Figure 9 : Tops gated communities and bottoms Squatted settlements

The tendency towards social exclusiveness and inward orientation for family homes is to be seen as an element of this zone. Within such a perspective, the enclosures could have been taken for a cultural relic as well. However, over recent years, socio-spatial segregation processes that, unlike in former years, create a spatial divide between "bottom squatted settlements' and "top gated communities".

\section{Bottom Squatted Settlements}

Before 1990s, however there were several spontaneous pockets in Zone B area and outside the indigenous walled city. Yet, the rapid expansion of such settlements has started since Gulf War in 1990. At the moment and for many reasons there is a continuation of expansion of squatted settlements in all directions mainly at the mountain foothills surrounding the capital. Squatted settlements are areas in which land is squatted on or subdivided without following an official subdivision plan and which are informally developed without adhering to any official planning and building regulations.

There are 39 informal areas in Sana'a host between roughly 390,000 inhabitants or 20.5 percent of the city's total population. Even though these are rather rough estimates, they clearly show that residential informality is a phenomenon of 
scale. Informal areas appear to accommodate a significant percentage of Sana'a's population growth. The 2004 census indicates an increase of 744,207 individuals in Sana'a during the period of 1994-2004. The population estimates suggest that around one third of these households have found housing in the 39 informal areas included in this study.

39 informal areas were identified in Sana'a. The areas were identified through analysis of satellite imagery and field visits. Types, settlements and building features in bottom squatted settlements are shown in Fig. (10).

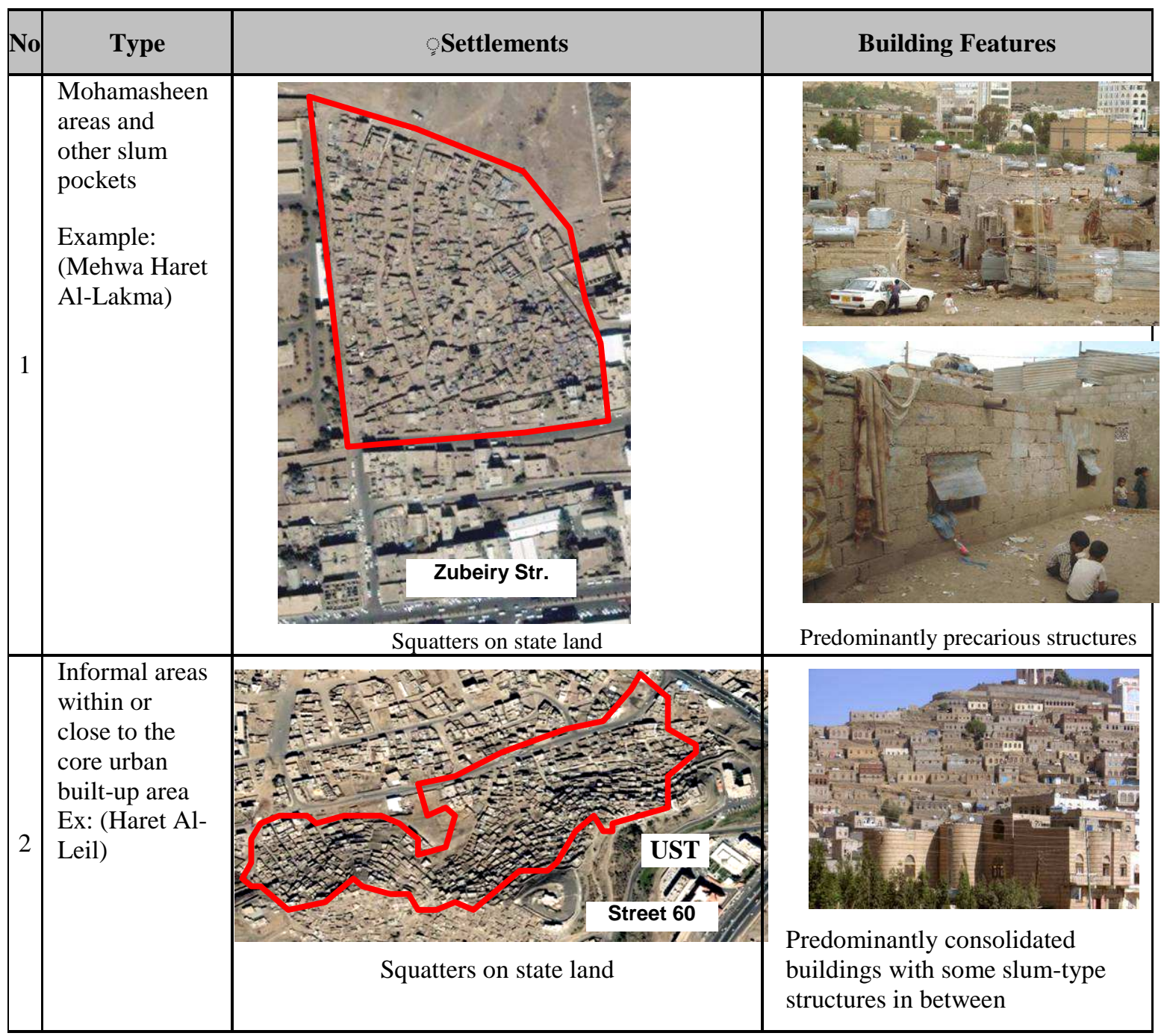




\begin{tabular}{|c|c|c|c|}
\hline 3 & $\begin{array}{l}\text { Informal } \\
\text { areas on the } \\
\text { far urban } \\
\text { fringe } \\
\text { alongside or } \\
\text { close to } \\
\text { major roads } \\
\text { Ex: } \\
\text { (Qa-Al- } \\
\text { Qaidi) }\end{array}$ & 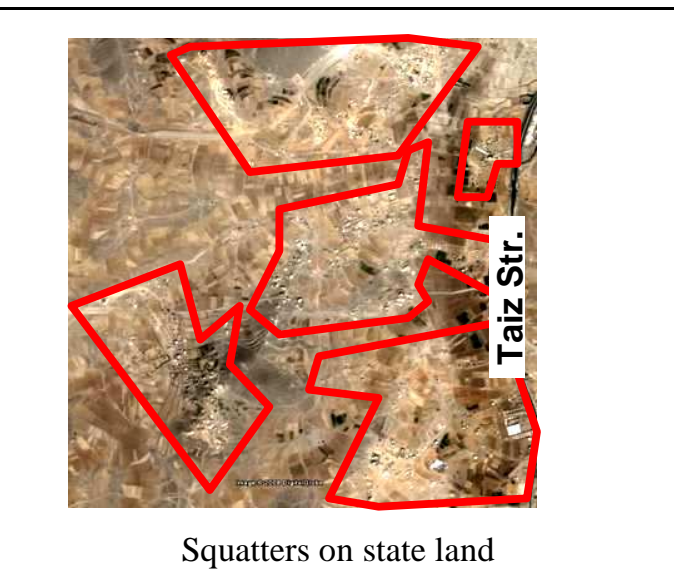 & $\begin{array}{l}\text { Mostly low cost buildings on } \\
\text { small plots that allow for gradual } \\
\text { expansion }\end{array}$ \\
\hline 4 & $\begin{array}{l}\text { Informal } \\
\text { areas on the } \\
\text { far urban } \\
\text { fringe } \\
\text { village } \\
\text { extensions } \\
\text { Ex: Aser } \\
\text { Village }\end{array}$ & $\begin{array}{l}\text { Squatters on state land or informal } \\
\text { construction on private agricultural land }\end{array}$ & $\begin{array}{l}\text { Mix of consolidated buildings, } \\
\text { small houses that are built } \\
\text { incrementally and some slum-type } \\
\text { structures }\end{array}$ \\
\hline 5 & $\begin{array}{l}\text { Informal } \\
\text { areas on land } \\
\text { that was } \\
\text { reserved for } \\
\text { the } \\
\text { preservation } \\
\text { of public } \\
\text { goods (water } \\
\text { resources and } \\
\text { security of } \\
\text { airport) } \\
\text { Ex: Hema Al- } \\
\text { Matar }\end{array}$ & $\begin{array}{l}\text { Mainly private agricultural land with some } \\
\text { encroachment on state land }\end{array}$ & P. \\
\hline
\end{tabular}




\begin{tabular}{|l|l|l|l|}
\hline $\begin{array}{l}\text { Informal } \\
\text { areas on } \\
\text { land that } \\
\text { was } \\
\text { reserved } \\
\text { for other } \\
\text { non- } \\
\text { residential } \\
\text { purposes } \\
\text { Ex: Al- } \\
\text { Hatarish }\end{array}$ & $\begin{array}{l}\text { Mainly private agricultural land with some } \\
\text { encroachment on state land. }\end{array}$ & $\begin{array}{l}\text { Mix of consolidated buildings and } \\
\text { small houses that are built } \\
\text { incrementally }\end{array}$ \\
\hline
\end{tabular}

Figure 10 : Types, settlements and building features in bottoms squatted settlements

As shown in Fig. (10) spontaneous dwellings have no specific form. The dwellings in those areas are grouped randomly, leaving a narrow access around them. These accesses are irregular in layout and they do not have a regular width. Nor are they built to a standard of specification or even "urf". The main element of the spontaneous areas is the residential dwelling, the settlers' main aim being to make maximum use of land, with the land that is left over being used as street. This has resulted in narrow winding streets, difficulties in getting access to some dwellings in these areas.

\section{Top Gated Communities}

Gated communities are defined as residential neighborhoods and settlements in which access to areas usually considered as open public spaces-streets and parks-is restricted only to local dwellers, their visitors and authorized service personnel. These neighborhoods are usually walled or fenced, secured by various security features, and their main entrances are usually controlled by guards. In some cases, access restrictions are not fully enforced, but the defining exclusionary feature of gated communities is the full or partial denial of access to the general public, rather than restrictions on the acquisition of dwelling units.

Although walls, gates and fences surrounding living villages in the Yemeni country side are not new, the development, structure, and extent of today's gated communities differ from their antecedents.

The origins of new gated communities in Sana'a can be traced to the early 1990s. Urban gated complexes, aimed at middle-class professionals and the rich and famous. They have emerged as the most type of gated communities in Sana'a. These complexes apply various control measures. That includes social dimensions (screening via housing prices and amenities on site) and physical features.

The physical features characterized by signs, humps, cement block barriers and some times security guards. It started by section and closer of public space and ended by exclusive quarters not accessible to public (Fig.11). 


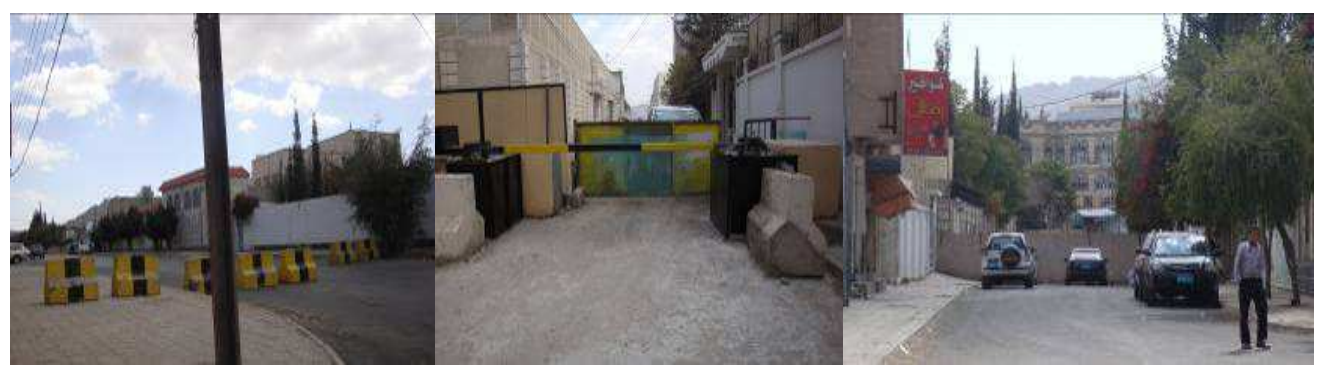

Figure 11: Exclusive quarters not accessible to public

In the case of privatizing the public space different scales of fences height are applied (Fig. 12).
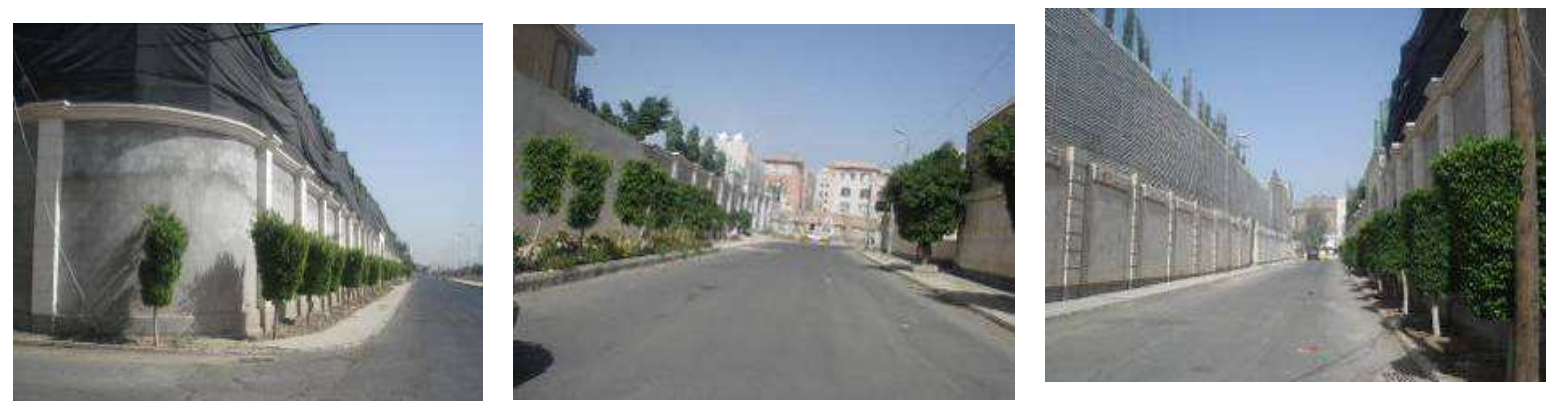

Figure 12: Different scales of fences height in gated complexes

That is to satisfy both privacy and safety measures. Intercom and surveillance technologies are also installed to ensure Security. Prestige is also not excluded.

As shown in Fig. (13), The typology of upper-class gated communities in Sana'a can be classified into three types as follows:

- The first type is high-rise condominiums constructed on private agricultural land. These condominiums are characterized by high-technology security, consumption and service facilities and private management.

- The second type is exclusive private villas. These are large in size and a variety of housing types; high-technology security and large private security personnel; top-notch communication, infrastructure and sport facilities; large variety of social services; private governance.

- The third type of gated communities includes detached single family houses. The exclusive plateau of (Tellal Alryan) in (Hadda) district is the perfect example of this type. The under construction project is targeting the wealthy residents (every detached dwelling unit costs one million US dollar). Strict closer is motivated by desire to enhance prestige, privacy and security.

When compared to bottom squatted settlements as shown in Table (1) top gated communities in Sana'a are characterized by creating exclusionary spaces, increasing residential segregation, restricting freedom of movement and exacerbating social divides. That is creating a "new urban segregation", which implies the internal space is 'purified' from 'different outsiders'. 


\begin{tabular}{|c|c|c|c|}
\hline No & Type & Settlements & Building Features \\
\hline 1 & $\begin{array}{l}\text { High-rise } \\
\text { Condomin } \\
\text { ium } \\
\text { (Hadda } \\
\text { District) }\end{array}$ & 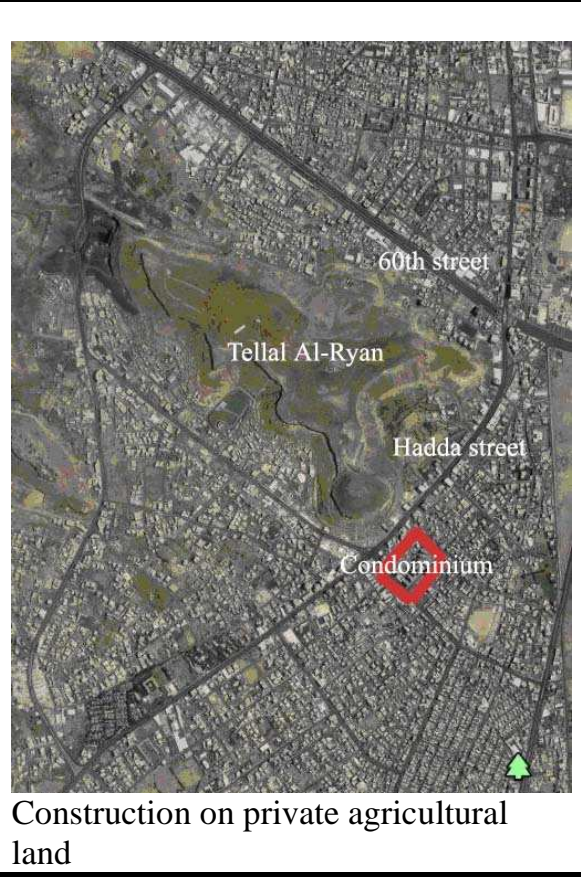 & $\begin{array}{l}\text { 5. } \\
\text { High-technology security; top consumption } \\
\text { and service facilities; private management. }\end{array}$ \\
\hline 2 & $\begin{array}{l}\text { Exclusive } \\
\text { villa } \\
\text { (Hadda } \\
\text { District) }\end{array}$ & 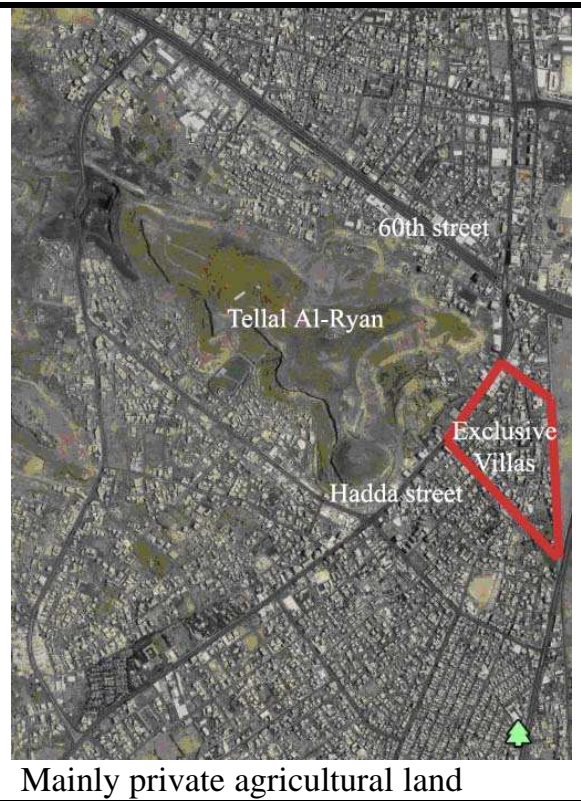 & $\begin{array}{l}\text { Large in size and a variety of housing types; } \\
\text { high-technology security and large private } \\
\text { security personnel; } \\
\text { communication, infrastructure and sport } \\
\text { facilities; large variety of social services; } \\
\text { private governance. }\end{array}$ \\
\hline
\end{tabular}




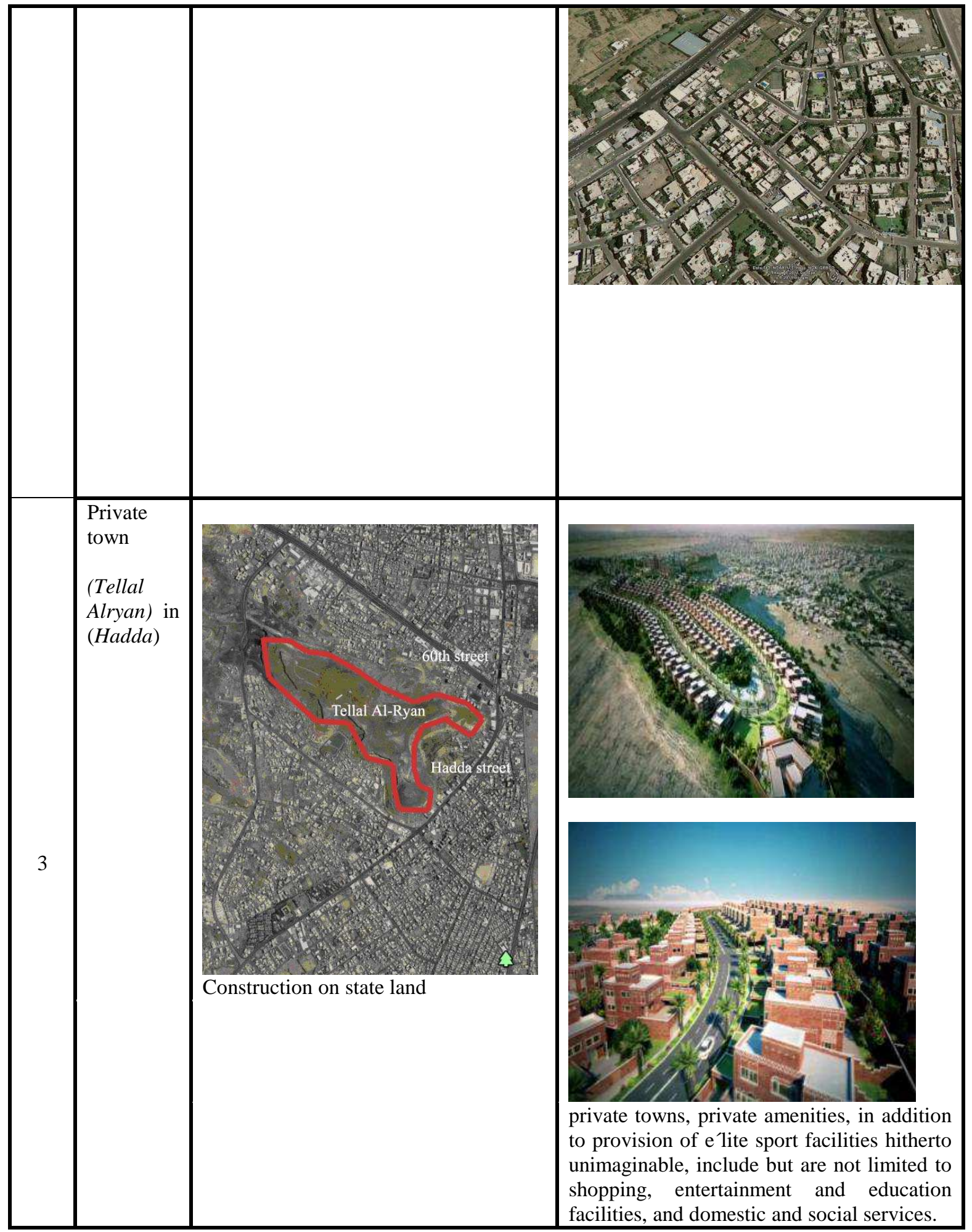

Figure 13: Typology of upper-class gated communities in Sana'a 
Table 1: Bottom squatted settlements vs. top gated communities in Sana'a city

\begin{tabular}{|c|c|c|c|c|c|}
\hline & \multirow{2}{*}{$\begin{array}{c}\text { Users Socio- } \\
\text { Economic } \\
\text { characteristics }\end{array}$} & \multicolumn{4}{|c|}{ Settlements } \\
\hline & & $\begin{array}{c}\text { Formation } \\
\text { process }\end{array}$ & Location & Types & Features \\
\hline $\begin{array}{l}\text { Bottom } \\
\text { squatted } \\
\text { settlements }\end{array}$ & $\begin{array}{l}\text { - } \text { Disadvantaged groups } \\
\text { - } \text { Concentrated of } \\
\text { poverty } \\
\text { - Social exclusion } \\
\text { - Rural identity } \\
\text { - Low educational level } \\
\text { - Unskilled labour }\end{array}$ & $\begin{array}{l}\text { Bottom-up } \\
\text { popular } \\
\text { initiatives } \\
\text { without } \\
\text { adhering to } \\
\text { any official } \\
\text { planning and } \\
\text { building } \\
\text { regulations. }\end{array}$ & $\begin{array}{l}\text { Mostly } \\
\text { enclaves and } \\
\text { pockets at the } \\
\text { fringes of the } \\
\text { city }\end{array}$ & $\begin{array}{l}\text { - Slum pockets } \\
\text { - Squatters close to } \\
\text { urban areas } \\
\text { - Squatters on far } \\
\text { urban fringe } \\
\text { - Squatters as } \\
\text { village extension } \\
\text { - on land reserved } \\
\text { for the } \\
\text { preservation of } \\
\text { public goods } \\
\text { - on land reserved } \\
\text { for other non- } \\
\text { residential } \\
\text { purposes } \\
\end{array}$ & $\begin{array}{l}\text { - Dwellings } \\
\text { merely as a } \\
\text { place to live } \\
\text { - No specific } \\
\text { for } \\
\mathrm{m} \\
\text { - Maximum } \\
\text { use of land } \\
\text { adapting to } \\
\text { topography }\end{array}$ \\
\hline $\begin{array}{l}\text { Top gated } \\
\text { communitie } \\
\text { s }\end{array}$ & $\begin{array}{l}\text { - Advantaged groups } \\
\text { - Concentrated of } \\
\text { wealth, prestige, } \\
\text { privacy, and security } \\
\text { - Urban identity } \\
\text { - High educational level } \\
\text { - Skilled labour } \\
\text { - Changing life style, } \\
\text { relations. } \\
\text { - Social } \\
\text { communications } \\
\text { (cyber space) }\end{array}$ & $\begin{array}{l}\text { Top-Down } \\
\text { public urban } \\
\text { planning } \\
\text { policies. }\end{array}$ & $\begin{array}{l}\text { Planned areas } \\
\text { at outskirts of } \\
\text { the city }\end{array}$ & $\begin{array}{l}\text { - High-rise } \\
\text { Condominium } \\
\text { - Exclusive villa } \\
\text { - Private town }\end{array}$ & $\begin{array}{l}\text { - Dwellings } \\
\text { to investment }\end{array}$ \\
\hline
\end{tabular}

As demonstrated above, these exclusionary practices are facilitated by cement block barriers, walls, security gates and surveillance existing to varying degrees in all gated communities. Residents tend to be socially similar and are able to function by cyber space beyond the physical limits of the communities and with limited interaction outside their walls, thus implying a homogeneous lifestyle with no (or very limited) contact with the 'difference' that exists in the unknown atmosphere of life 'beyond the gate'. Thus, spatial separation becomes intertwined with social exclusion.

\section{CONCLUSIONS}

This study confirms the emergence of a new direction of social segregation in Sana'a city in the past two decades. This phenomenon has been observed in the line of most Third World cities and the global trend of privatizing the public space.

This paper demonstrates that the social segregation in the city is associated with "the spatial separation of different social groups in a geographic area according to differences, of income, among others". It is possible to visualize in the city the different districts where each social group has its own specific space. The high-income 
groups can choose their planned gated locations, while the impoverished groups are isolated in pockets of squatted settlements in the fringe of the city.

The reason to fence it in is resulting from the socio-economic transformation in the city. The economic growth has widened income gap, as more and more wealth has been accumulated by the upper class, resulting in a growing jealousy, and a growing need for security. In addition to cultural background, privacy and security always seem to be the basis for such developments. However, with the growth of upper middle classes, prestige and lifestyle become the reason. What ever the reason is this sealing off has therefore been rightly an indication of a new direction of socio-spatial segregation processes. Unlike social interaction in the "sarha" in the old gated city, they create a socio-spatial divide not only between the "rich gated complexes", but also between them and the squatted poor settlements.

Gated communities, in one hand do not only deepen socio-cultural fragmentation along with spatial segregation, but also create a separation between 'insiders' of this communities and 'outsiders of them. By supporting private solutions to common urban problems, gated communities encourage institutionalisation of a socially and spatially stratified urban citizenship. Those who can afford to live in private neighbourhoods have political empowerment and can access quality infrastructure and amenities, while others are powerless and excluded from basic infrastructure because of their social and economic status.

The squatted settlements, on the other hand, should not be viewed as part of the cities' housing crisis but rather as the urban poor contribution to its solution. Steps should be taken towards their inclusion, legitimization, regularization and incorporation into the legal city. Urban planning processes and practices should be reviewed and adjusted so as to facilitate the development of land, legalization and housing for low-income groups. Land and housing sector policies, specifically those addressing the housing needs of the urban poor need also be reassessed and reformed accordingly.

\section{REFERENCES}

1. Al-Abed, A. (2003), "The development of Housing in Sana'a: Changes of Housing Form from Indigenous to Spontaneous", Journal of Science \& Technology, vol.(8), No. (1), pp.3-15.

2. Al-Taher Engineering Consultant (A.E.C), (2005),"Principles of Architectural Design and Urban Planning in the Different Islamic Eras: analytical study the Case of Yemen Capital Sana'a" Organization of Islamic Capitals and Cities, Jeddah, Saudi Arabia.

3. Atkinson, R. and Blandy, S. (2005) Introduction: international perspectives on the new enclavism and the rise of gated communities, Housing Studies, 20, pp. 177-186.

4. Blakely, E. and Snyder, M. (1997) Fortress America: Gated Communities in the United States.Washington, DC: Brookings Institution Press.

5. De La Rocha, G., Perlman, J., Safa, H., Jelin, E., Roberts, B. R. \& Ward, P. (2004) From the marginality of the 1960s to the new poverty of today: ALARR forum, Latin American Research Review, 39(1). 
6. Fainstein, N. (1996) A note on interpreting American poverty, in: E. Mingione (Ed.) Urban Poverty and the Underclass, pp. 153-159 (London: Blackwell).

7. Genis, S. (2007) Producing élite localities: the rise of gated communities in Istanbul, Urban Studies, 44, pp. 771-798.

8. Glasze, G., Webster, C. and Frantz, K. (2006) Introduction: global and local perspectives on the rise of private neighborhoods, in: G. Glasze, C. Webster and K. Frantz (Eds) Private Cities: Global and Local Perspectives, pp. 1-8. London: Routledge.

9. Marcuse, P. (1997) The ghetto of exclusion and the fortified enclave: new patterns in the United States, American Behavioral Scientist, 41, pp. 311-326.

10. Marcuse (1996) Space and Race in the post-Fordist city: The outcast ghetto and advanced homelessness in the United States today, in: E. Mingione (Ed.) Urban Poverty and the Underclass, pp. 176-216 (London: Blackwell).

11. McKenzie, E. (2005) Constructing the Pomerium in Las Vegas: a case study of emerging trends in American gated communities, Housing Studies, Geography, 20, pp. 513-533.

12. Pini, D., Lanzoni,L., Teston, S. (2008) The Inventory of the Historic City of Sana'a A Tool for Urban Conservation, UNESCO press.

13. Portes, A. \& Hoffman, K. (2003) Latin American class structures: Their composition and change during the neoliberal era, Latin American Research Review, 38(1).

14. Wacquant, L. J. D. (1996) Red belt, black belt: Racial division, class inequality and the state in the French urban periphery and the American ghetto, in: E. Mingione (Ed.) Urban Poverty and the Underclass, pp. 234-274 (London: Blackwell).

15. Webster, C., Glasze, G. and Frantz, K. (2002) Guest editorial: the global spread of gated communities, Environment and Planning B, 29, pp. 315-320.

\section{أحياء الترف المسورة وأحياء الفقر العثوائية:

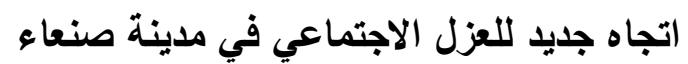

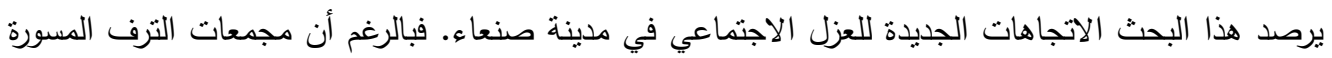

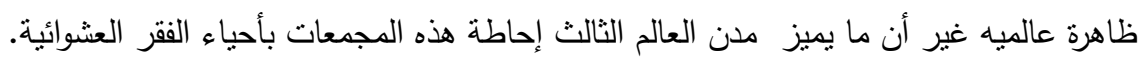
ففي مدينة صنعاء ومنذ ستينات القرن الماضي نطورت ظاهرة العزل الاجتماعي مع نمو الكتلة العمرانية للمدينة الذي يمكن تصنيفه إلى ثلاث مراحل هي على النوالي: المنطقة النقليدية والهنطقة الانتقالية والمنطقة العشوائية.

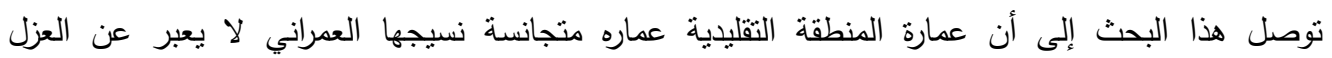

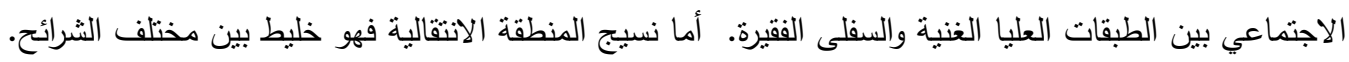

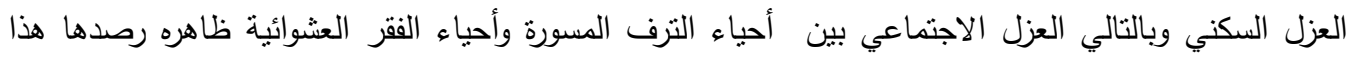
البحث في الامتداد العمراني على أطراف المدينة. 